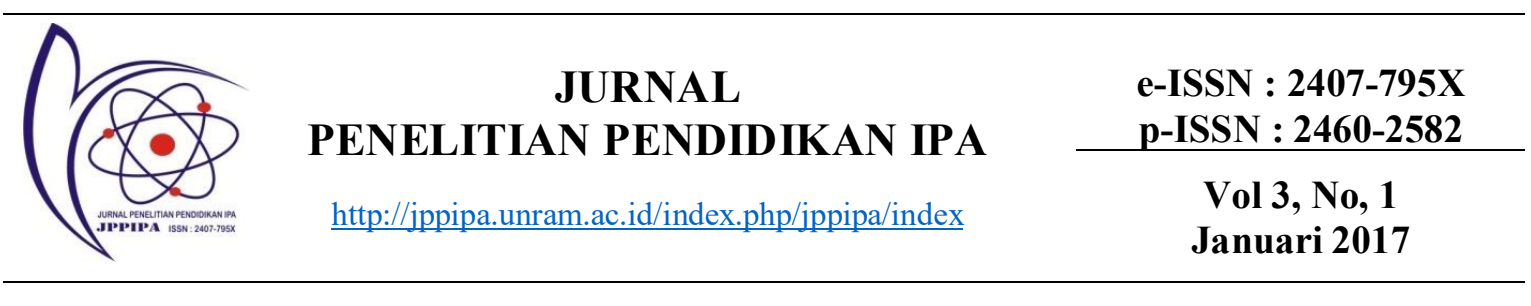

\title{
ANALISA VARIASI PEMBELAJARAN PADA MAHASISWA PROGRAM MAGISTER PENDIDIKAN IPA UNIVERSITAS MATARAM
}

Kosim, Susilawati, Aris Doyan dan Ahmad Harjono

kosim.unram@gmail.com

\begin{tabular}{ll}
\hline Key Words & Abstract \\
\cline { 2 - 3 } $\begin{array}{l}\text { Variation of } \\
\text { Instruction, }\end{array}$ & Descriptive study was conducted in order to determine the level of variation \\
Teaching & University of Mataram. Important research carried out in connection with \\
style, Multi & one of the competencies of teaching skills as a graduate Master of Science \\
Representat & Education. Data collection method for the analysis of variations in \\
ion & instruction styles questionnaire used learning and teaching as well as a \\
Approach & process for learning with multi representation approach on the subject of \\
& wave phenomena The population as well as a sample are students of Master \\
& of Science Education 2015/2016 and 2016/2017. The results of data \\
& processing of the variety of instruction based teaching style show $34.35 \%$ \\
& visual, $31.71 \%$ auditory and $33.94 \%$ kinestetic. While the level of variation \\
& of Instruction based on a total score of 45.50\% in good category. Results \\
& variety of instruction with a multi representation provides a good level of \\
& $50.00 \%$.
\end{tabular}

\begin{tabular}{|c|c|}
\hline $\begin{array}{l}\text { Kata } \\
\text { Kunci }\end{array}$ & Abstrak \\
\hline $\begin{array}{l}\text { Variasi } \\
\text { Pembelajar } \\
\text { an, Gaya } \\
\text { Mengajar, } \\
\text { Pendekatan } \\
\text { Multi } \\
\text { Representas } \\
\text { i }\end{array}$ & $\begin{array}{l}\text { Penelitian yang bersifat deskriptif telah dilaksanakan dengan tujuan untuk } \\
\text { mengetahui level variasi pembelajaran pada mahasiswa Magister Pendidikan } \\
\text { IPA Program Pascasarjana Universitas Mataram. Penelitian penting } \\
\text { dilakukan sehubungan dengan salah satu kompetensi kemampuan mengajar } \\
\text { sebagai lulusan Magister Pendidikan IPA. Metode pengumpulan data untuk } \\
\text { analisis variasi pembelajaran digunakan angket gaya belajar dan mengajar } \\
\text { dengan skala Likert, serta disajikan suatu proses pembelajaran dengan } \\
\text { pendekatan multirepresentasi pada pokok bahasan penomena gelombang.. } \\
\text { Populasi sekaligus menjadi sample adalah mahasiswa Magister Pendidikan } \\
\text { IPA angkatan } 2015 / 2016 \text { dan } 2016 / 2017 \text {. Hasil pengolahan data terhadap } \\
\text { variasi pembelajaran berdasarkan gaya mengajar menunjukkan gaya } \\
\text { mengajar visual } 34,35 \% \text {, auditory } 31,71 \% \text { dan kinestetik } 33,94 \% \text {. } \\
\text { Sedangkan level variasi pembelajaran berdasarkan skor total gaya mengajar } \\
45,50 \% \text { pada katagori baik. Hasil variasi pembelajaran dengan pendekatan } \\
\text { multi representasi memberikan } 50,00 \% \text { level baik. }\end{array}$ \\
\hline
\end{tabular}


PENDAHULUAN

Program pendidikan pada Progam Magister Pendidikan IPA di Program Pascasarjana Universitas Mataram, merupakan salah satu wahana untuk memperkuat atau menumbuh kembangkan kualitas guru. Banyak faktor yang mempengaruhi kualitas seorang guru. Pemerintah melalui kementerian Pendidikan Nasional telah menetapkan bahwa ada 4 aspek kompetensi kualitas guru yakni: kompetensi profesi, kompetensi paedagogik, kompetensi kepribadaian dan kompetensi sosial. Keempat kompetensi tersebut secara tidak tersirat berada dalam kurikulum Program Magister Pendidikan IPA. Sesuai dengan latar belakang pendidikan mahasiwa, maka pada program pendidikan Magister IPA ini terkonsentrasi dalam 3 bidang keahlian, yakni Magister Pendidikan IPA konsentrasi Fisika, Magister pendidikan IPA konsentrasi Kimia dan Magister pendidikan IPA konsentrasi Biologi

Hasil penelitian terdahulu pada kompetensi paedagogik sebagai kemampuan dasar keterampilan mengajar mahasiswa Magister pendidikan IPA konsentrasi Fisika (kosim dkk, 2014), menunjukkan bahwa untuk penguasaan variasi dalam pembelajaran dan kemampuan bertanya dalam proses belajar mengajar (PBM) mendapatkan rata-rata skor yang rendah.
Disadari bahwa salah satu usaha meningkatkan kualitas pembelajaran adalah dengan meningkatkan kualifikasi akademik guru. Peranan guru sangat menentukan dalam proses peningkatan kualitas hasil pendidikan. Peran dan fungsi guru yang sangat strategis dalam upaya peningkatan kualitas pendidikan menurut Miarso (2008), bahwa untuk melaksanakan fungsinya dengan baik guru wajib untuk memiliki salah satu syarat tertentu diantaranya adalah kompetensi. Ada 4 kompetensi yang harus dimiliki guru yakni kompetensi professional, kompetensi paedagogik, kompetensi kepribadian dan kompetensi sosial. Namun kompetensi yang lebih berhubungan dengan kemampuan mengajar adalah pada kompetensi professional dan kompetensi paedagogik. Pada kedua kompetensi ini akan kita perhatikan pada mahasiswa program magister pendidikan IPA program pasca sarjana Univ. Mataram dimana mereka sebagian besar berasal dari para guru di sekolah menengah. Oleh kaena itu, kualifikasi seorang guru dalam hal mengajar dapat diobservasi mulai dari pengetahuannya mengenai hal yang berhubungan dengan pembelajaran hingga penampilan saat bekerja.

Peneltian ini bertjuan untuk menganalisis bagaimana variasi dalam pembelajaran pada mahasiswa Magister 
pendidikan IPA, melalui pemberian angket dan sajian pembelajaran dengan pendekatan multirepresentasi topik materi fisika yang pesertanya teridiri dari 3 konsentrasi bidang keahlian yaitu fisika, kimia dan biologi.

\section{KAJIAN PUSTAKA}

Pengertian mengajar menurut Wati (2010) secara deskriptif diartikan sebagai proses menyampaikan informasi atau pengetahuan dari guru, kepada siswa. Merujuk pada pengertian mengajar tersebut, inti dari mengajar adalah proses menyampaikan (transfer), baik berupa ilmu pengetahuan maupun keterampilan. Makna dari menyampaikan ini adalah "menyebarluaskan, memperkaya" pengalaman belajar siswa sehingga dapat mengembangkan potensinya secara maksimal. Makna lain dari pengertian mengajar sebagai proses menyampaikan adalah menanamkan pengetahuan, sikap dan keterampilan, sehingga potensi berfikir (pengetahuan), sikap, keterampilan, kebiasaan dan kecakapan yang dimiliki siswa akan berkembang secara optimal. Semua kegiatan pembelajaran tersebut bertitik tolak dari kemampuan guru mengadakan variasi dalam pembelajarannya.

$$
\text { Menurut Hasibuan }
$$

menyebutkan bahwa menggunakan variasi diartikan sebagai perbuatan guru dalam konteks proses belajar mengajar yang bertujuan mengatasi kebosanan peserta didik, sehingga dalam proses belajarnya peserta didik senantiasa menunjukkan ketekunan, keantusiasan, serta berperan secara aktif. Pengertian variasi menunjukkan bahwa dalam kegiatan mengajar guru hendaknya melakukan hal yang membuat pembelajaran tidak monoton.

Teori variasi dalam pembelajaran dapat dilakukan atas dasar gaya belajar peserta didik. perbedaaan gaya belajar itu menunjukkan cara tercepat dan terbaik bagi setiap individu bisa menyerap sebuah informasi dari luar dirinya. Oleh karena itu, sebagai seorang guru bisa memahami bagaimana perbedaan gaya belajar pada peserta didiknya. Gaya belajar garis besarnya meliputi gaya belajar visual, auditory dan kinestetik. . Gaya belajar visual menyangkut penglihatan dan bayangan mental. Gaya belajar pendengaran (Auditory) merujuk pada pendengaran dan pembicaraan. Gaya belajar kinestetik merujuk gerakan fisik yang dilakukan peserta didik saat belajar.

Tinjauan variasi gaya mengajar jika kita memperhatikan gaya belajar individu peserta didik. Guru harus memperhatikan kebiasaan belajar peserta didik, baik kemampuan dia dalam membaca buku pelajaran serta keterampilan lain yang diperlukan seperti 
membuat ringkasan, cara menghafal, membuat catatan dari buku teks, mendiskusikan isi buku, menjawab soal dan mengerjakan tugas-tugas yang ada dalam buku teks/ buku pelajaran yang dibacanya ( Kosim, 1988).

Mung (2012) juga menyebutkan bahwa variasi dalam pembelajaran dapat dinyatakan dengan hadirnya variasi aktivitas bagi peserta didik melalui pemberian LKPD (Lembaran Kerja Peserta Didik) dalam upaya memahami materi pelajaran.

Variasi dalam mengajar dapat pula disajikan melalui suatu pendekatan pembelajaran. Pendekatan Multirepresentasi merupakan salah satu bentuk yang lebih menarik dalam memberikan variasi dalam mengajar. Prain \& Waldrip (2007) menuliskan bahwa representasi merupakan sesuatu yang mewakili, menggambarkan, atau menyimbolkan objek dan/atau proses. Multirepresentasi berarti merepresentasi ulang konsep yang sama dengan format yang berbeda, termasuk verbal, gambar, grafik, dan matematik.

\section{METODE PENELITIAN}

$\begin{array}{lrr}\text { Jenis } & \text { penelitian ini } & \text { merupakan } \\ \text { penelitian } & \text { deskriptif, } & \text { yang } \\ \text { menggambarkan situasi dan kondisi saat } & \\ \text { ini pada populasi yang diteliti. Deskripsi }\end{array}$

sekitar tingkat pengetahuan responden dalam melaksanakan variasi pembelajaran pada mahasiswa Magister Pendidikan IPA Pascasarjana Unram

Populasi penelitian adalah mahasiswa Magister Pendidikan IPA angkatan 2015/2016 dan 2016/2017. Populasi ini sekaligus menjadi sampel saat penelitian. Pengambilan sampel merupakan responden yang hadir saat pengambilan data dan terkumpul $83 \%$ dari jumlah populasi.

Pengambilan dan pengumpulan data digunakan melalui angket dengan Item pernyataan gaya belajar dan mengajar yang meliputi gaya visual, audirory dan kinestetik. Skala yang digunakan merupakan skala Likert dari 1 sampai 3, dengan pilihan "Ya" skor 3, "Kadang-kadang" skor 2 dan "tidak" skor 1. Sedangkan untuk respon pembelajaran dengan pendekatan multirepresentasi diberikan kepada satu kelas angkatan 2016/2017. Angket respon diberikan dengan skala likert 1 sampai 4. Dengan kriteria pemilihan sebagai berikut (Tabel 1) 
Tabel 1. Pilihan jawaban pada angket pendekatan pembelajaran multirepresentasi

\begin{tabular}{lcl}
\hline Pilihan & Skor & Kriteria pernyataan \\
\hline ST & 4 & Jika mengetahui dan biasa melakukan \\
T & 3 & Jika mengetahui dan pernah melakukan \\
KT & 2 & Jika baru tahu dan tidak melakukan \\
TT & 1 & Jika sebelumnya tidak tahu \\
\hline
\end{tabular}

Formulasi untuk menentukan kriteria pembelajaran ditentukan dalam 3

Level penguasaan keterampilan variasi katagori sebagai berikut (Tabel 2):

Tabel.2 Kriteria Level kemampuan gaya mengajar VAK dan Pendekatan Multirepresentasi pada mahasiswa Magister Pendidikan IPA Unram

\begin{tabular}{|c|c|c|c|c|}
\hline Level & $\begin{array}{l}\text { DATA SKOR } \\
\text { Gaya mengajar visual, } \\
\text { auditory dan kinesteti } \\
\text { (VAK) }\end{array}$ & Kriteria & $\begin{array}{l}\text { DATA SKOR } \\
\text { Gaya mengajar } \\
\text { pendekatan } \\
\text { Multirepresentasi }\end{array}$ & Kiteria \\
\hline Baik & $\begin{array}{l}\mathrm{X} \max =75 \\
\mathrm{X} \min =48\end{array}$ & $\begin{array}{l}\geq \mathrm{MI}+0,5 \mathrm{SDI} \\
\geq 63,75\end{array}$ & $\begin{array}{l}X \max =78 \\
X \min =49\end{array}$ & $\begin{array}{l}\geq \mathrm{MI}+0,5 \mathrm{SDI} \\
\geq 66\end{array}$ \\
\hline Cukup & $\begin{aligned} \mathrm{MI} & =1 / 2(\mathrm{Xmax}+\mathrm{Xmin}) \\
& =61,5\end{aligned}$ & $\begin{array}{l}\text { MI- } 0,5 \text { SDI sd MI }+0,5 \text { SD } \\
59,25 \mathrm{sd} \ldots 63,75\end{array}$ & $\begin{aligned} \mathrm{MI} & =1 / 2(\mathrm{X} \max +\mathrm{Xmin}) \\
& =63,5\end{aligned}$ & $\begin{array}{c}\text { MI- 0,5SDI sd MI +0,5SDI } \\
61 \text { sd } 66\end{array}$ \\
\hline Kurang & $\begin{aligned} \mathrm{SDI} & =1 / 6(\mathrm{Xmax}-\mathrm{Xmin}) \\
& =4,5\end{aligned}$ & $\begin{aligned} \ldots \ldots \ldots \ldots & <\mathrm{MI}-0,5 \mathrm{SDI} \\
& <59,25\end{aligned}$ & $\begin{aligned} \mathrm{SDI} & =1 / 6(\mathrm{Xmax}-\mathrm{Xmin}) \\
& =4,8\end{aligned}$ & $\begin{aligned} \cdots \ldots \ldots \ldots & <\mathrm{MI}-0,5 \mathrm{SDI} \\
& <61\end{aligned}$ \\
\hline
\end{tabular}

\section{HASIL DAN PEMBAHASAN}

\section{A. Deskripsi Variasi Pembelajaran melalui pandangan Gaya Mengajar dan Belajar pada Mahasiswa Magister IPA.}

Mahasiswa

Magister

Pendidikan IPA sebagaian besar terdiri dari para guru kelompok IPA, yaitu konsentrasi pendidikan fisika, kimia dan biologi. Keterampilan mengadakan variasi dalam pembelajaran dapat meliputi tiga hal yaitu variasi dalam gaya mengajar, variasi dalam menggunakan media dan bahan pengajaran dan variasi dalam interaksi antara guru dengan siswa. Respon angket telah diberikan kepada mahasiswa magister pendidikan IPA mengenai gaya belajar mereka dan juga gaya mengajarnya pada komponen visual, auditory dan kinestetik.

Data gaya belajar mahasiswa magister IPA terkumpul 55 responden dari 63 orang, dengan total item 60 pernyataan ditunjukan pada grafik 1 berikut ini. 


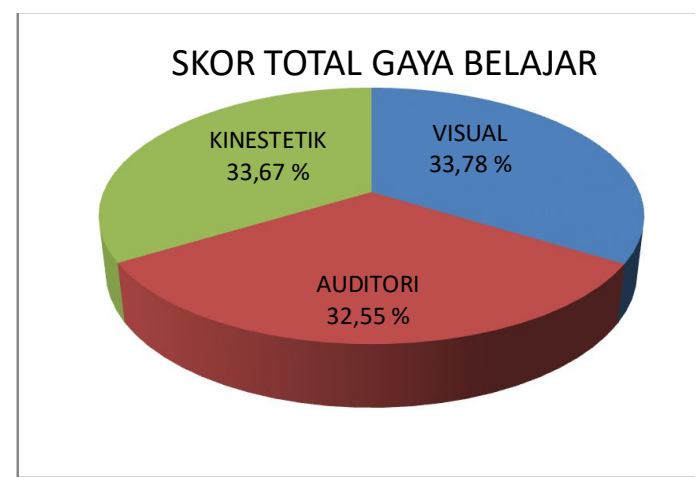

Grafik 1. Gaya Belajar mahasiswa Magister IPA

Sedangkan hasil gaya mengajar pada responden yang sama, dengan jumlah pertanyaan 27 item ditunjukkan pada grafik 2

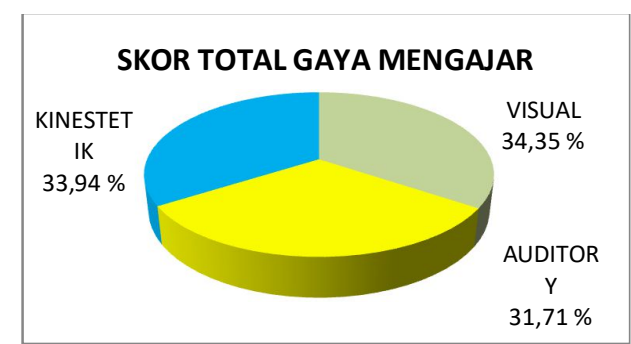

Grafik 2. Gaya Mengajar mahasiswa Magister IPA

Jika kita memperhatikan korelasi gaya belajar responden sebagai mahasiswa Magister Pendidikan IPA dan kemampuan variasi mengajarnya sebagai Guru di sekolah dapat ditunjukkan dengan grafik 3 sebagai grafik regresi. Grafik ini di olah berdasarkan kriteria nilai skala 100 untuk data gaya belajar dan gaya mengajar.

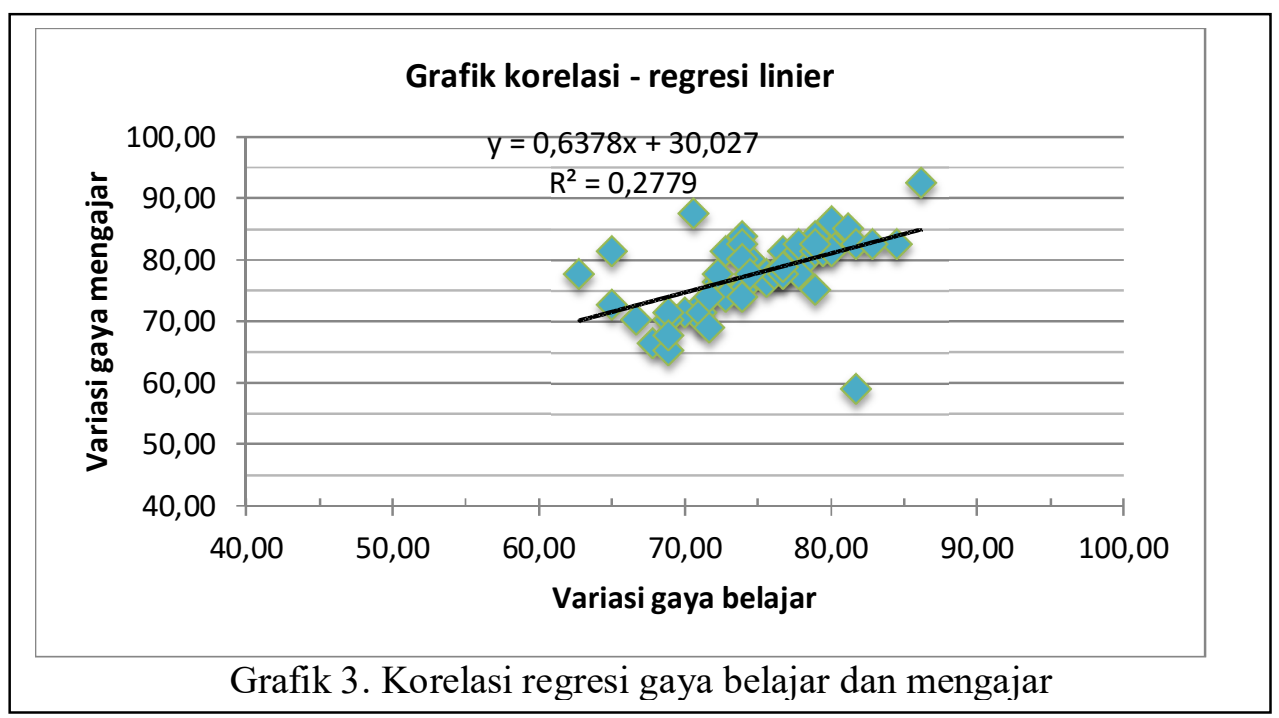

Grafik 4 tersebut menunjukkan adanya korelasi positif bahwa gaya belajar responden mempengaruhi kemampuan keterampilan gaya mengajarnya. Artinya semakin variasi gaya belajar yang dilakukannnya bervariasi, maka keterampilan 
variasi gaya mengajarnyapun akan bervariasi pula. Sumbangan pengaruh gaya belajar terhadap kemampuan keterampilan variasi gaya mengajar adalah $27,7 \%$.

Jika dilihat dari level kemampuan variasi mengajar berdasarkan skor total individu dari 3 komponen visual, auditory dan kinestetik mengacu kriteria tabel 2 dapat dilihat pada grafik 3 berkut ini.

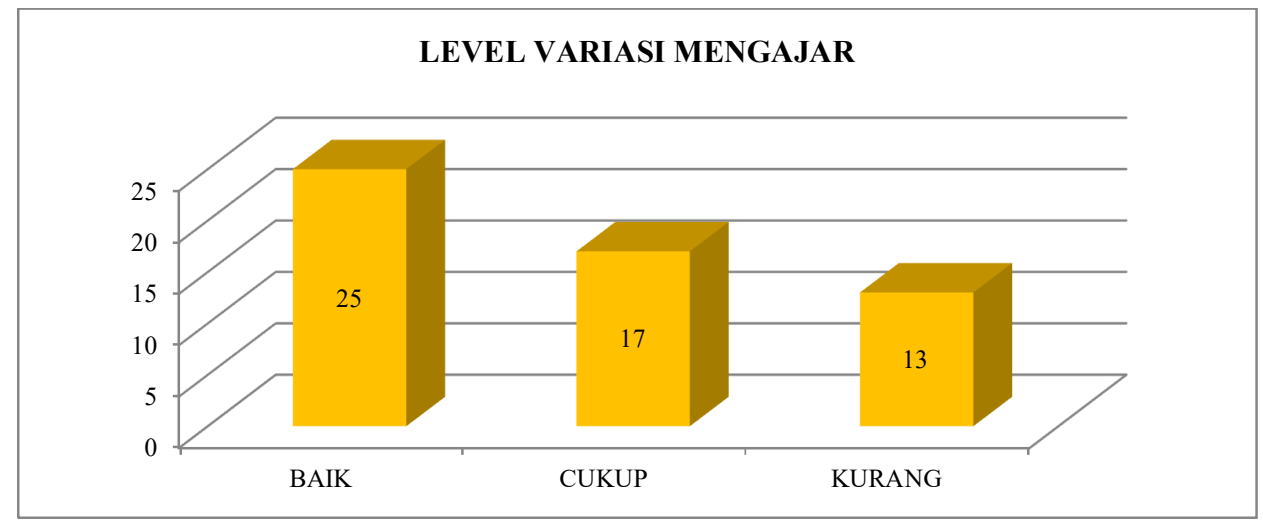

Grafik 3. Level variasi gaya mengajar VAK Mahasiswa S2 Pendidikan IPA

Pada grafik 3 tersebut menunjukkan bahwa terdapat 25 responden pada level variasi baik dapat menerapkan gaya mengajarnya, 17 responden pada level cukup dan 13 responden pada level kurang. Deskripsi dari data tersebut adalah bagi responden yang berada pada level baik menunjukkan bahwa variasi gaya mengajarnya baik gaya visual, auditory maupun kinestetik menunjukkan rata-rata telah melaksanakan variasi gaya mengajar tersebut. Mereka yang termasuk pada level baik sebesar 45,5\%. Artinya kemampuan pada gaya mengajar dalam memfasilitasi gaya belajar visual, auditory dan kinestetik rata-rata lebih baik. Sedangkan mereka yang berada pada level kurang, menunnjukkan bahwa variasi gaya mengajar baik visual,auditory maupun kinestetik secara rata-rata belum melaksanakan. Mereka yang berada pada level kurang ini, diperkirakan cenderung kurang bisa melayani variasi gaya belajar yang ada pada siswanya. Sesuai hasil penelitian sari (2014) bahwa pada dasarnya gaya belajar pada siswa merupakan variasi gabungan dari gaya visual, auditory dan 
kinestetik, tetapi mereka mempunyai kecenderungan yang lebih menonjol pada gaya belajar tertentu. Penelitiannya pada mahasiswa Informatika menunjukkan bahwa kecenderungan pada gaya belajar visual $53 \%$ lebih menonjol dibanding gaya belajar lainnya. Hubungan gaya mengajar dalam memfasilitasi kemampuan gaya belajar siswa dalam visual, auditory maupun kinestetik mempengaruhi prestasi belajar siswanya (Angganing, 2011). Oleh karena itu penting bagi guru untuk mengenali gaya belajar siswanya.

\section{B. Deskripsi Variasi Pembelajaran melalui pandangan pendekatan Multirepresentasi pada Mahasiswa Magister IPA}

Pembelajaran

fisika

menggunakan multirepresentasi dapat dilakukan dalam dua bentuk. Bentuk pertama adalah dalam proses belajar mengajar, dan bentuk kedua adalah dalam proses asesmen (Yusup. 2009). Langkah-langkah yang dilakukan dengan menggunakan multirepresentasi dalam proses pembelajaran adalah :

1. Mengidentifikasi konsep-konsep kunci. Setiap representasi dapat membantu peserta didik untuk memahami dan menggunakan konsep-konsep kunci dalam fisika. Langkah awal adalah mengidentifikasi konsep konsep tersebut dan memikirkan bagaimana peserta didik dapat mengambil manfaat dari representasi-representasi yang disajikan

2. Mengkonstruksi representasi lain. Menurut peneliti peserta didik diajak untuk merekonstruksi suatu konsep dalam bentuk lain.sesuai gaya belajar atau daya penalaran peserta didik.

Sedangkan multi representasi dalam proses assesmen dapat diberikan berupa soal dalam variasi bentuk verbal, piktorial ( visual), grafik ataupun matematik.

Melalui presentasi dengan power point, materi ajar Penomena Gelombang disajikan sesuai konsep multirepresentasi yang berisi gambar, persamaan matematik, grafik dan contoh penyelesaian soal. Selain itu selama proses pembelajaran kepada peserta pembelajar diberikan pula LKPD ( Lembaran Kerja Peserta Didik) berupa soal dalam variasi bentuk verbal, piktorial ( visual), grafik ataupun matematik 
Variasi mengajar dengan konsentrasi Pendidikan Kimia, 6 pendekatan Multirepresentasi pada mahasiswa dengan konsentrasi materi penomena gelombang telah Pendidikan Biologi dan 8 mahasiswa disajikan kepada satu kelas magister dengan konsentrasi Pendidikan Fisika. IPA semester I angkatan angkatan 2016/2017, dimana mahasiswan yang hadir 24 orang yang terdiri dari 10 mahasiswa magister IPA dengan Prosentase respon pengalaman mereka yang berhubungan dengan pendekatan Multirepresentasi ditunjukkan pada

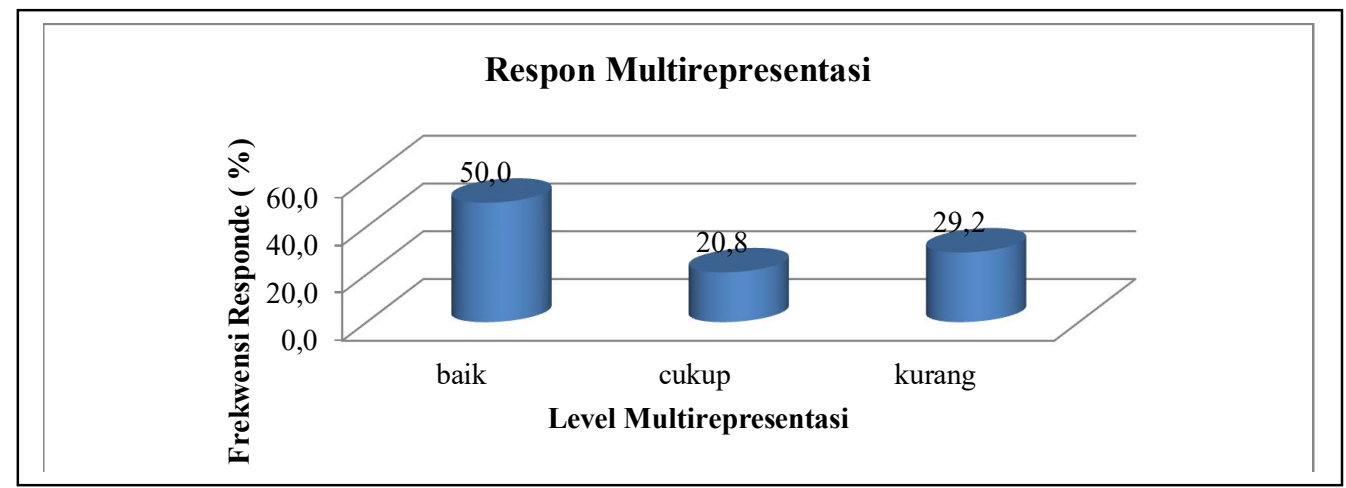

Grafik. 4. Respon terhadap variasi pembelajaran dengan pendekatan Multirepresntasi Pada grafik 4 mendeskripsikan bahwa Hasil rerata Nilai dari LKPD pengetahuan responden mengenai variasi pembelajaran melalui pendekatan Multirepresentasi adanya ketertarikan dengan level baik $50 \%$, level cukup 20,8 \% dan level kurang $29,2 \%$ selama pembelajaran berlangsung dan TEST yang diberikan diakhir pembelajaran, selanjutnya disebut sebagai hasil belajar, diperoleh skor rerata per-konsentrasi pendidikan ditunjukkan pada grafik 5. sebagai berikut

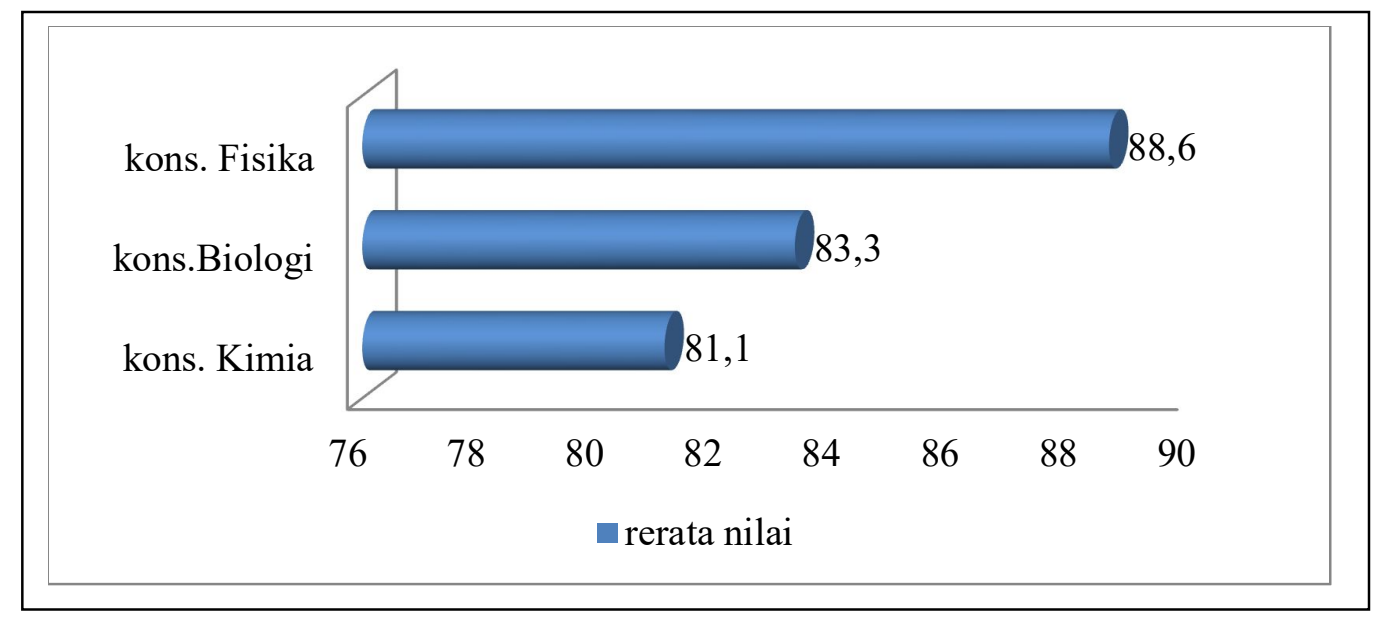

Grafik. 5. Rerata Nilai hasil pembelajaran dengan pendekatan Multi Representasi materi Gelombang 
Grafik 5. menunjukkan, bahwa walaupun materi gelombang adalah bahasannya konsentrasi pendidikan Fisika, tetapi mahasiswa pendidikan dengan konsentrasi pendidikan Kimia dan Biologi juga dapat memahami isi materi tersebut. Terbukti ketiga konsentrasi itu mendapatkan nilai rerata di atas 80,0 .

Sesuai hasil penelitian Suhandi dan Wibowo (2012) bahwa pendekatan multi representasi materi fisika pokok bahasan energi dan usaha pada mahasiswa jurusan pendidikan Matematika di salah satu LPTK di Jawa Barat menunjukkan penggunaan pendekatan ini efektif dalam memberikan pemahaman konsep fisika pada mahasiswa. Selain itu Yusuf (2009) dari hasil penetiannya menyatakan bahwa pendekatan multi reprenstasi yang melalui representasi verbal, gambar, grafik/diagram dan matermatik dapat membantu peserta didik dalam memahami konsep-konsep fisika.

\section{KESIMPULAN}

Pada deskripsi hasil dan
pembahasan terhadap analisa variasi
pembelajaran pada mahasiswa
Magister IPA diperoleh kesimpulan
sebagai berikut:

1. Secara umum mahasiswa magister IPA angkatan 2015/2016 dan 2016/2017 telah mengenal dan melaksanakan variasi mengajar melalui gaya mengajar visual, auditory dan kinestetik.

2. Variasi pembelajaran Fisika melalui pendekatan Multirepresentasi menunjukkan bahwa pembelajar ( Mahasiswa Magister IPA konsentrasi Kimia, Biologi dan Fisika) memberikan respon positif dengan bukti hasil kegiatan belajar diperoleh rerata skor di atas 80

\section{DAFTAR PUSTAKA}

.2013. Pedoman Akademik. Program Studi Magister Pendidikan IPA, program Pascasarjana Universitas Mataram. Mataram

Angganing, P. 2011. Hubungan antara Gaya Mengajar Guru dan Sikap Peserta Didik dengan Prestasi belajar peserta didik kelas 5 di kecamatan Wnogiri. Skripsi. FKIP Universitas Sebelas Maret. Surakarta.

Effendi, M. Y. 2008. Analisis Kualifikasi dan Kompetensi Profesi Guru serta Upaya Pengembangannya dalam Menyikapi UU Guru-Dosen (studi di Pendidikan Dasar dan Menengah Kota Malang). FKIP Univ. Muhamadiyah Malang. Penelitian Dosen Muda - DIKTI. 
Hardianto, D. 2009. Pendidikan Guru dan Upaya Meningkatkan Professional Guru. Seminar nasional IPTPI tanggal 18 November.Yogyakata.

Kosim. 1989. Hubungan Antara cara memelajari buku teks fisika dengan prestasi belajar fisika pada siswa kelas II program $A_{1}$ di SMAN 3 Bandung. (skripsi).

Kosim. 2014. Tingkat Pengetahuan Keterampilan Dasar Mengajar pada Mahasiswa Program Magister Pendidikan IPA Di Program Pascasarjana Universitas Mataram. (Laporan Penelitian )

Kyriacou, C. 2007. Essential Teaching Skills. Third edition. Nelson Thornes LTD. United Kingdom.

Lo, M. L. 2012. Variation Theory and the Improvement of Teaching and Learning. Acta Universitatis Gothoburgensis. Goteborg Universitat.

Miarso, Y. 2008. Peningkatan Kualifikasi Guru dalam Perspektif Teknologi Pendidikan, Jurnal Pendidikan Penabur, No10/tahun ke 7 bulan Juni. Jakarta

Ridwan. 2010. Penelitian Tindakan Kelas Pendidikan Dasar. PT. Pajar Andika Harta. Banyuwangi

Roshensine, B. 2012. Principle of Instruction. JOURNAL. AMERICAN EDUCATOR, SPRING, USA

Sari, A. K. 2014. Analisis Karakteristik Gaya Belajar VAK ( Visual, Auditory dan Kinestetik) Mahasiswa Pendidikan Informatika Angkatan 2014.
Jurnal Ilmiah Edutic. Vol.1, no.1.Nopember 2014.

Suhandi, A dan F.C. Wibowo. 2012. Pendekatan Multi representasi dalam Pembelajaran UsahaEneri dan Dampak terhadap Pemahaman Konsep Mahasiswa. Jurnal pendidikan Fisika Indonesia. ISSN : 1693-1245, Januari, 2012.

Suhandi, A dan F.C. Wibowo. 2012 Pendekatan Multirepresentasi dalam Pembelajaran Usaha dan Energi. Dan Danpak terhadap pemahaman Konsep mahasiswa. Jurnal Pendidikan Fisika Indonesia VOL. 8 hal. 1-7

Sujarwo dan Delnitawati. 2012 Pengaruh Metoda Pembelajaran dan Gaya Belajar terhadap Hasil Belajar. Laporan Penelitian. Fakultas Keguruan dan Ilmu Pendidikan Universitas Muslim Nusantara (UMN) AlWashliyah Jl. SM.Raja/Garu II No. 93 Medan 20147

Wati, W. 2010. Keterampilan Dasar Mengajar (Makalah Strategi Pembelajaran). Program Pasca sarjana. Universits Negeri Padang.

Wragg, E. C. 2005. The Art and Science of Teaching and Learning: The Selected Works of Ted Wragg. Routledge Falmer. London

Yusup. M. 2009. Multirepresentasi dalam Pembelajaran Fisika. Seminar Nasional Pendidikan FKIP UNSRI, 14 Mei 2009 di Palembang 